\title{
The Role of Client and Employee Concern in the Relationship between Organizational Governance and Corporate Social Responsibility (CSR) Adoption
}

\author{
Pui-Sze CHOW (Corresponding author) \\ Centennial College (An Independent College Established by HKU) \\ 3 Wah Lam Path, Pokfulam, Hong Kong \\ Tel: 852-3762-6291Ｅ-mail: linda.psl.chow@centennialcollege.hku.hk
}

Amy C.Y. YIP

City University of Hong Kong

Tat Chee Avenue, Kowloon, Hong Kong

Tel: 852-3442-9230Ｅ-mail: amy.cy.yip@cityu.edu.hk

Received: Sep. 4, $2016 \quad$ Accepted: Sep 29, $2016 \quad$ Published: October 1, 2016

doi:10.5296/jmr.v8i4.9986 URL: http://dx.doi.org/10.5296/jmr.v8i4.9986

\begin{abstract}
This paper explores the strategic consideration of organizational governance for CSR adoption. Specifically, it develops a conceptual framework that outlines how an organization's concern for its clients and employees influences the relationship between organizational governance and various domains of CSR behaviors. Based on survey data from organizations that are actively engaged in CSR in Hong Kong, there is evidence that adoption of client-oriented CSR practices complementarily mediates the positive relationship between organizational governance and CSR practices in all areas except those related to community involvement and development. On the other hand, adoption of employees-oriented CSR practices is a complementary mediator for the positive relationship between organizational governance and CSR practices related to the environment and the community.
\end{abstract}

Keywords: Corporate social responsibility (CSR), organizational governance, strategic CSR, client-oriented CSR, employee-oriented CSR 


\section{Introduction}

Corporate social responsibility (CSR) has become a standard item in the agenda for many firms and institutions nowadays. With the rising public concern, organizations in both the private and the public sectors have to pay more attention to the social and environmental impacts of their activities. Apart from maintaining their legitimacy (Suchman, 1995), there is a growing number of organizations that recognize the competitive advantages brought about by CSR and thus begin to take a strategic approach to their CSR adoption (Porter \& Kramer, 2006).

Whereas a myriad of literature discuss and provide evidence for the strategic value of CSR, there is apparently a lack of studies that considers the mechanism behind such value creation. To shed lights on the aspect, this paper aims at exploring the strategic consideration of organizational governance for CSR adoption. Specifically, this paper investigates how an organization's concern for its clients and employees influences the relationship between organizational governance and various domains of CSR behaviors. The hypotheses are verified statistically by survey data.

This paper contributes to the literature by empirically examining the strategic concern of organizational governance towards CSR. It extends the existing literature by adopting an endogenous view on the relationship between organizational governance and CSR (Devinney, Schwalbach, \& Williams, 2013). It also bridges the gap in the extant literature by exploring how interaction of multiple dimensions of organizational governance affects CSR adoption. (Jain \& Jamali, 2016).

The remainder of the paper is organized as follows. The next section devotes to a review of the literature relevant to this study and an elaboration of the proposed theoretical framework. Then, a description of the methodology and the empirical results follows. Afterwards, theoretical and managerial implications of the findings are discussed. The paper ends with a conclusion that addresses limitations of the study and provides future research directions.

\section{Theoretical Background and Hypotheses}

\subsection{Corporate Social Responsibility (CSR)}

CSR deals with "the economic, legal, ethical and discretionary expectations that society has of organizations at a given point in time" (Schwartz \& Carroll, 2003). Davis (1973) considers CSR as a company's undertaking of the obligation beyond legal requirements. Wood (1991) identifies three principles of social responsibility, namely: the obligations of managers to socially responsible decision-making (individual level), responsibility of the firm to the society owing to its operations natures (organizational level), and the legitimacy of the firm as a member in the society (institutional level). The studies of CSR comprise a vast variety of directions, including the below popular topics: the relationships with stakeholders (e.g. Clarkson, 1995; Harrison \& Freeman, 1999), CSR disclosure (e.g. Abbott \& Monsen, 1979; Fifka, 2013), as well as CSR and performance (e.g. McGuire, Sundgren, \& Schneeweis, 1988; Saeidi, Sofian, Saeidi, Saeidi, \& Saaeidi, 2015). 


\subsection{Strategic Value of CSR}

A stream of literature examines the strategic value of CSR. Branco and Rodrigues (2006) and McWilliams and Siegel (2011) separately study the strategic value of CSR with reference to the resource-based theory. Porter and Kramer (2006) contend that business and society are interdependent and that the strategic approach of CSR can bring competitiveness to firms as well as solve social issues. Falck and Heblich (2007) regard CSR as a win-win strategy for both the business and the society to prosper. Porter and Kramer (2011) espouse the notion of shared value creation which emphasizes the relationship between economic and societal values. In fact, a considerable amount of works have demonstrated the positive relationship between CSR and financial performance (e.g. Cochran \& Wood, 1984; Waddock \& Graves, 1997; Lo, Yeung, \& Cheng, 2012). McWilliams and Siegel (2001) found the existence of a profit-maximizing level of CSR investment that can fulfill the demands from different stakeholders for CSR. Rhodes and Keogan (2005) focus on the non-profit sector and investigate the factors that affect the choices of strategy by non-profit organizations. Jamali, (2007) examines the various strategic CSR practices of eight Lebanese companies. Galbreath (2010) finds evidence that firms of different strategy types have different extents of CSR adoption.

\subsection{Relationship between Organizational Governance and CSR adoption}

The relationship between organizational governance and CSR has been asserted by a huge amount of literature. For instance, Husted (2003) compares different forms of governance with respect to CSR implementation and identifies key factors that affect the choice of CSR-related governance. Ho (2005) shows that commitments to social responsibilities are positively associated with stewardship and strategic leadership of boards. Aguilera, Williams, Conley and Rupp (2006) attribute the differences in the concern for CSR between firms in US and UK to the different corporate governance structures between the two countries. Hammann, Habisch, and Pechlaner (2009) empirically show that the personal value of SME entrepreneurs on social responsibility positively influences on firm performance. Husted, Allen, and Rivera (2010) contend that internal CSR engagement will be more likely for a firm that has a closer fit between its CSR activities and its mission and objectives. Jo and Harjoto (2012) and Ntim and Soobaroyen (2013) separately find empirical evidence that corporations with better governance tend to have a higher degree of CSR engagement. The latter also show that corporate governance could strengthen the relationship between CSR and corporate financial performance.

An organization is said to have a high degree of governance in CSR if it has clear objectives for social responsibility, with its senior management demonstrating commitment and accountability to create and nurture a culture for CSR throughout the organization (ISO, 2010). The Strategic Choice Theory takes the view that senior executives of an organization are capable of influencing the organization by making choices amongst different courses of strategic actions in a dynamic and political manner (Child, 1997). In this respect, an organization with a high degree of CSR aspects of governance reflects its management's acceptance of its responsibility as a corporate citizen and thus would be more readily to 
engage in CSR practices. A high degree of organizational governance also ensures effective allocation of resources for successful deployment of CSR initiatives, which in turn can better realize the strategic value of CSR practices. For examples, Porter and Kramer (2002) regard philanthropy as one of the most cost-effective means to enhance a firm's competitiveness when it can produce social and economic benefits simultaneously. Organizational governance thus plays an important role to align the interest of the organization and the social good by working out the approach to philanthropy that is most appropriate to the organization and subsequently enables the capture of the competitiveness brought about. For risk management purpose, an organization with a high extent of governance would evaluate all possible risks and concerns that may arise from the operations of the organization from different sources and try to take preventive actions whenever possible. Perez-Batres, Doh, Miller and Pisani (2012) investigate how pressures from different stakeholders influence the firms' strategic decision to adopt self-regulatory codes of conduct regarding their environmental practices. Organizational governance therefore safeguards the interest of the organization by reacting to institutional pressure and maintaining the licence to operate. On the other hand, organizational governance develops the vision and mission of an organization and ensures execution and compliance of the direction throughout the organization. For instance, Meyer and Smith (2000) find that employees' perceived organizational support mediates the relationship between human resources management practices (such as career development, training and benefit packages) and employee commitment. By upholding a clear stance of CSR, organizational governance enables both internal and external stakeholders to be more confident toward the organizations' attitude towards CSR and be better prepared to coordinate with the organization's CSR initiatives. In light of the above, we posit Hypothesis 1 as follows:

Hypothesis 1. Organizational governance positively influences the extent of CSR adoption in different domains.

\subsection{Mediating Effect of Client Concern ${ }^{1}$}

The strategic choice perspective of CSR emphasizes on the competitiveness it brings about to organizations. Polonsky and Jevons (2009) consider CSR as a branding strategy and discuss three aspects for effective leverage of CSR activities by global brands, namely: issue definition, coordination of internal and external activities for effective undertaking of global CSR activities, and communication of CSR initiatives. On the other hand, Delmas and Toffel (2008) obtain empirical evidence that the decision to adopt environmental management system such as ISO 14001 is affected by the perceived pressures from the outside market constituents as well as from the corporate marketing departments within the organizations. We argue that all CSR activities practiced by an organization, whether they are client-oriented or not, can directly or indirectly affect the relationship between the organization and its clients. Intuitively, clients are directly influenced by the practices of the organization that are related to their welfare, such as consumer health and safety protection, unbiased information, fair contractual practices, and consumer data protection and privacy (ISO, 2010)). On the

\footnotetext{
${ }^{1}$ In this paper, we use the term "clients" to refer to customers who purchase products/services from firms or users who utilize services provided by an agency in the public sector.
} 
other hand, adoption of CSR practices in other domains, can also affect clients' perception towards the organization. In particular, organizations that fail to be compliant to universal values such as those related to human right, labour condition, and environmental protection, would be despised by clients who uphold those ethical values. The ultimate consideration for organizations lies on whether they can fulfill their objectives to serve their clients. In this respect, we argue that an organization with a high adoption level of client-oriented CSR practices tend to accent its CSR agenda in other domains. Accordingly, we have Hypothesis 2 as follows:

Hypothesis 2. The adoption of client-oriented CSR practices complementarily mediates the positive relationship between organizational governance and the other aspects of CSR practices.

\subsection{Mediating Effect of Employee Concern}

In this study, we also posit the mediating effect of employee-oriented CSR practices on community-oriented CSR practices and environmental practices. To a certain extent, a high level of adoption in employee-oriented CSR practices reflects an organization's the emphasis on employee welfare. From the perspective of social exchange theory (Cropamzano \& Mitchell, 2005), a high degree of perceived organizational support is positively associated with employees' engagement in organizational citizenship behavior (Lynch, Eisenberger, \& Armeli, 1999; Saks, 2006). Management commitment with proper employee training and empowerment could enhance the environmental performance of an organization (Govindarajulu \& Daily, 2004; Sarkis, Gonzalez-Torre, \& Adenso-Diaz, 2010). On the contrary, a company with weak business culture and human resources may be hindered from effective environmental management (Daily \& Huang, 2001). Accordingly, we have Hypotheses $3 \mathrm{a}$ and $3 \mathrm{~b}$ as follows:

Hypothesis 3a. The adoption of employee-oriented CSR practices complementarily mediates the positive relationship between organizational governance and the community-oriented CSR practices.

Hypothesis $3 b$. The adoption of employee-oriented CSR practices complementarily mediates the positive relationship between organizational governance and the environmental practices.

\section{Methodology}

\subsection{Sample and Data Collection}

Data for hypothesis testing were collected from a questionnaire survey administered in Hong Kong. The sample consists of members from either of the below two groups: (1) awardees of the Caring Company/Organization Scheme and (2) publicly listed companies on the Main Board of Hong Kong Exchanges and Clearing Limited. Introduced in 2002, the Caring Company/Organization Scheme is a widely recognized labeling system in the territory that acclaims businesses and organizations with prominent performance in CSR according to a set of nomination criteria. Listed companies, on the other hand, are deemed to be more compliant 
to CSR adoption and disclose their associated performance. The two groups are active practitioners in CSR and are believed to constitute an appropriate sample frame for this study.

Self-administered questionnaires were mailed twice to the senior management of the target organizations, such as the chief executive officer or director, from April to September 2015. The initial mailing resulted in 152 usable responses. A follow-up mailing was sent six weeks after the initial mailing and further solicited 134 usable responses. As a result, a final sample size of 286 was retained.

Assuming late respondents behave similarly as non-respondents, a non-response bias analysis was conducted by comparing the responses to the first mailing with those to the second mailing (Armstrong \& Overton, 1977). T test was conducted to compare between the responses of two groups but no differences were found at the 5\% significance level. Therefore, non-response may not be a problem for this study.

Around $60 \%$ of the respondent organizations are large in size with over 100 employees. Over half $(53.8 \%)$ of them have operations outside Hong Kong. A majority of them (74\%) have been adopting CSR for at least five years.

\subsection{Measures}

\subsubsection{Six Constructs of CSR}

We adapt Chow, Tang and Yip (2016) to measure respondent organizations' extent of CSR adoption. The scale was developed with reference to the ISO 26000 standard (ISO, 2010), one of the widely adopted international standards in social responsibility. In the set of questionnaire, respondents were asked to evaluate on a five-point Likert scale (from "1 = very low extent" to " 5 = very high extent") the extent to which their organizations performed in six areas of CSR, namely: organizational governance (OG), human rights (HR), labour practices (LP), environmental concern $(\mathrm{EN})$, consumer protection $(\mathrm{CP})$, and community involvement \& development (CID). In particular, the construct OG refers to the governance aspect of an organization's approach to CSR whereas the construct CP measures the extent of CSR adoption an organization undertakes that are directly related to the welfare of its client. Accordingly, to test Hypothesis 1, we examine the association between the construct OG and the other five constructs. For Hypothesis 2, we investigate the mediating effect of the construct $\mathrm{CP}$ on the relationship between $\mathrm{OG}$ and the remaining four constructs. For Hypotheses $3 \mathrm{a}$ and $3 \mathrm{~b}$, we look for any mediating effect of the construct LP on the relationship between $\mathrm{CP}$ and $\mathrm{CID}$, and that between $\mathrm{CP}$ and $\mathrm{EN}$, respectively.

\subsubsection{Control Variables}

Similar to prior research, two control variables are considered in this study, namely: organization size and operation span. For instance, based on survey data, Machold, Huse, Minichilli, and Nordqvist (2011) show that leadership behaviors and processes matter more for board strategy involvement in small companies than structural leadership characteristics. Observed from a sample of companies from 42 countries, Ioannou and Serafeim (2012) suggest that different countries would have different corporate social performance. We 
measure the size of an organization by the number of employees (Baurn, Locke, \& Smith, 2001; Brunninge, Nordqvist, \& Wiklund, 2007). Specifically, respondent organizations with 100 employees or less were categorized as "small" whilst those with over 100 employees as "large" organizations. Regarding operation span, respondent organizations were classified into two groups, namely: one that operates in Hong Kong only, and one that has operations outside Hong Kong.

\subsection{Methods}

The hypotheses were tested through structural equation modeling (SEM) using the AMOS (version 23) software to generate maximum likelihood parameter estimates. The measurement model was first scrutinized by confirmatory factor analysis (CFA). Various metrics for model fit, reliability and validity assessment were compared with benchmarks employed in the literature (Hair, Black, Babin, \& Anderson, 2010; Hu \& Bentler, 1999; Nunnally, 1978). Measurement invariance and common method variance were also examined.

Measurement invariance signifies whether items adapted in a measurement scale "mean the same things to members of different groups" (Cheung \& Rensvold, 2002). It is pivotal to establish measurement invariance before conducting cross-group comparisons so to ensure that any subsequent findings are due to genuine attitudinal differences instead of different psychometric responses (Cheung \& Rensvold, 2002). Amongst the various types of measurement invariance, configural invarinace and metric invariance are considered to be pre-requisites for meaningful subsequent tests (Vandenberg \& Lance, 2000). Configural invariance pertains to the beliefs that different groups share the same concept of the constructs. It can be demonstrated by a good overall fit for the multigroup confirmatory factor analysis (MGCFA). On the other hand, a measurement model is said to achieve metric invariance if there are no differences in all factor loading parameters across groups. In this paper, MGCFA and multigroup moderation tests were performed to assess measurement invariance.

Common method variance (CMV) refers to the systematic error shared amongst constructs owing to various aspects during the measurement process (such as single source of data, illusory correlations amongst items, common scale properties, and social desirability, etc.) instead of that is due to the constructs being measured (Podsakoff, MacKenzie, Lee, \& Podsakoff, 2003). It can bias estimation of construct reliability and validity as well as parameter estimates of the relationship between constructs (Podsakoff, MacKenzie, \& Podsakoff, 2012), which in turn result in misinterpretation of the observed relationships (Johnson, Rosen, \& Djurdjevic, 2011). The approaches of Chang, Gong and Peng (2012) and Kulik, Cregan, Metz and Brown (2009) were adopted in this paper to test for CMV.

We utilize the Stats Tools Package developed by Gaskin (2016a) to test for reliability, validity, measurement invariance and CMV. Afterwards, we examine the fit of the structural model and perform subsequent hypothesis testing. 


\section{$\Lambda$ Macrothink}

\section{Results}

\subsection{Measurement Model}

\subsubsection{Model fit}

The measurement model had demonstrated an adequate model fit in light of most fit indicators: the chi-square statistic per degree of freedom $(\mathrm{CMIN} / \mathrm{DF}=1.683, \mathrm{p}<0.001)$ was below 3 despite the significant chi-square statistic; comparative fit index $(\mathrm{CFI}=0.972)$ was greater than 0.95 ; adjusted goodness of fit $(\mathrm{AGFI}=0.897)$ was greater than 0.8 ; root mean square error of approximation $(\mathrm{RMSEA}=0.049)$ was less than 0.05 ; PCLOSE $(=0.544)$ was also greater than 0.05 . Hence, the model fit adequately met the thresholds contended in the literature (Hu \& Bentler, 1999). Besides, the factor loadings of all items ranged between 0.688 and 0.952 , all of which were statistically significant $(\mathrm{p}<0.001)$ and were well above the 0.40 threshold (Nunnally, 1978).

\subsubsection{Reliability and validity verification}

Tables 1 and 2 showed the various measures for testing reliability and validity. Construct reliability could be assumed with the following evidence from Table 1: (i) The values of composite reliability (CR) for all constructs exceeded 0.7 ; and (ii) The values of maximal reliability $\mathrm{H}$ statistic $(\mathrm{MRH})$ were above 0.8 for all constructs (Hancock \& Mueller, 2001). Observed from Table 2, no convergent validity issue was observed as the values of average variance extracted (AVE) for all constructs exceeded 0.5. Discriminant validity of the constructs was also verified as: (i) the AVE was greater than the respective maximum shared variance (MSV) for all constructs; and (ii) the square root of AVE of a construct was greater than the largest inter-construct correlation associated to it. To sum up, the measurement model achieved adequate reliability and validity with reference to the thresholds proposed in the literature (Hair et al., 2010). 
Table 1. Statistics for construct reliability check

\begin{tabular}{|c|c|c|c|c|c|c|}
\hline Construct & & Item & Mean & S.D. & $\mathbf{C R}$ & MRH \\
\hline \multirow[t]{3}{*}{$\begin{array}{l}\text { Organizational } \\
\text { governance (OG) }\end{array}$} & 01 & $\begin{array}{l}\text { Development of CSR strategies, objectives } \\
\text { and targets }\end{array}$ & 3.79 & .779 & .861 & .928 \\
\hline & 02 & Leadership commitment and accountability & 3.95 & .825 & & \\
\hline & 03 & $\begin{array}{l}\text { Creation and nurturing of an environment } \\
\text { and culture for CSR }\end{array}$ & 3.85 & .790 & & \\
\hline \multirow[t]{3}{*}{ Human rights (HR) } & 04 & $\begin{array}{l}\text { Free from discrimination (e.g. race, colour, } \\
\text { gender, age, religion, etc.) }\end{array}$ & 4.41 & .752 & .877 & .954 \\
\hline & 05 & Respect freedom of opinion and expression & 4.34 & .697 & & \\
\hline & 06 & Respect right to life and liberty & 4.39 & .680 & & \\
\hline \multirow[t]{2}{*}{$\begin{array}{l}\text { Labour practices } \\
\text { (LP) }\end{array}$} & 07 & $\begin{array}{l}\text { Human development and training in the } \\
\text { workplace }\end{array}$ & 4.21 & .723 & .741 & .959 \\
\hline & 08 & Health and safety at work & 4.44 & .640 & & \\
\hline \multirow{3}{*}{$\begin{array}{l}\text { Environmental } \\
\text { concerns }(\mathrm{EN})\end{array}$} & 10 & Prevention of pollution & 4.14 & .732 & .865 & .968 \\
\hline & 11 & Sustainable use of resources & 4.10 & .662 & & \\
\hline & 12 & $\begin{array}{l}\text { Protection and restoration of the natural } \\
\text { environment }\end{array}$ & 3.95 & .739 & & \\
\hline \multirow[t]{4}{*}{ Client Concern (CC) } & 13 & Anti-corruption & 4.65 & .595 & .865 & .869 \\
\hline & 16 & $\begin{array}{l}\text { Fair marketing, factual and unbiased } \\
\text { information }\end{array}$ & 4.38 & .729 & & \\
\hline & 17 & Protecting consumers' health and safety & 4.42 & .730 & & \\
\hline & 18 & Consumer data protection and privacy & 4.50 & .694 & & \\
\hline \multirow{2}{*}{$\begin{array}{l}\text { Community } \\
\text { involvement and } \\
\text { development (CID) }\end{array}$} & 20 & $\begin{array}{l}\text { Employment creation and skills } \\
\text { development }\end{array}$ & 4.02 & .747 & .818 & .976 \\
\hline & 21 & Technology development and access & 3.90 & .751 & & \\
\hline
\end{tabular}

Note: S.D.: standard deviation; CR: composite reliability; $\quad$ MRH: maximal reliability H statistic.

Table 2. Statistics for validity check

\begin{tabular}{|c|c|c|c|c|c|c|c|c|c|}
\hline Construct & \multirow{2}{*}{ MSV } & \multirow{2}{*}{ AVE } & \multirow{2}{*}{$\begin{array}{c}\text { Square } \\
\text { root of } \\
\end{array}$} & & & \multicolumn{6}{|c|}{ Pearson correlation coefficients } \\
\cline { 5 - 10 } & & & AVE & & HR & LP & EN & CC & CID \\
\hline OG & .483 & .674 & .821 & 1.000 & & & & & \\
\hline HR & .446 & .704 & .839 & .485 & 1.000 & & & & \\
\hline LP & .524 & .589 & .768 & .695 & .522 & 1.000 & & & \\
\hline EN & .411 & .682 & .826 & .569 & .489 & .637 & 1.000 & & \\
\hline CC & .524 & .563 & .751 & .546 & .668 & .724 & .641 & 1.000 & \\
\hline CID & .412 & .697 & .835 & .642 & .407 & .636 & .473 & .533 & 1.000 \\
\hline
\end{tabular}

Note: AVE: Average variance extracted; MSV: maximum shared variance. 


\subsubsection{Measurement invariance}

In this study, organization size and operation geography were two control variables under investigation. To ensure unambiguous interpretation of any possible between-group differences derived from subsequent analysis, we followed the procedure of Gaskin (2012) to conduct invariance tests. First, multigroup confirmatory factor analysis (MGCFA) was performed with the sample data split along organization size ("large" versus "small"). The resultant models preserved a good fit $(\mathrm{CMIN} / \mathrm{DF}=1.607, \mathrm{p}<0.001 ; \mathrm{CFI}=0.965$; AGFI $=$ 0.869 ; RMSEA $=0.033$; PCLOSE $=1.000)$. In other words, configural invariance was achieved. Next, we conducted a multigroup moderation test with the use of critical ratios for differences in AMOS (Gaskin, 2016b). No significant differences were observed between the groups of large and small size for all measurement items except one in the construct HR. Therefore, metric invariance was also assured between groups of different organization sizes. Similarly, we split the sample data along operation scope ("Hong Kong only" versus "with operation outside Hong Kong") and performed the above tests again. The model fit of the MGCFA was adequate $(\mathrm{CMIN} / \mathrm{DF}=1.580, \mathrm{p}<0.001$; $\mathrm{CFI}=0.966$; $\mathrm{AGFI}=0.868$; $\mathrm{RMSEA}=$ 0.032 ; PCLOSE $=1.000$ ). The multigroup moderation test result also reflected no significant differences between respondent organizations with local operations and those have operations outside Hong Kong except for all measurement items except one in the construct CC. Hence, the measurement model and factor loadings were adequately equivalent across groups with different organization sizes and different operation span.

\subsubsection{Common method variance}

We follow the approaches of Chang et al. (2012) and Kulik et al. (2009) to test for CMV. To be specific, we added in our original measurement model an unmeasured method factor with its variance set to 1 and all items loaded to it with loadings free to vary (hereafter called the method model). At the same time, we consider another model which is equivalent to the method model except that all item loadings were set to 0 (hereafter called the zero-constrained model). Then, we compared the fit between these two models and calculate the amount of variance attributed to the method factor.

The method model generated a good fit $(\mathrm{CMIN} / \mathrm{DF}=1.409, \mathrm{p}<0.01 ; \mathrm{CFI}=0.987$; AGFI $=$ 0.92 ; RMSEA $=0.038$; PCLOSE $=0.906$ ). The chi-square difference test showed that the method model had a better fit than the zero-constrained model $\left(\Delta \chi^{\wedge} 2=52.597, \Delta \mathrm{df}=17, \mathrm{p}\right.$ $<0.001)$ but it may be vulnerable to sample size. Alternatively, as an indicator of practical significance, the difference in CFI (Byrne, 2001) between the two models $(=0.014)$ was less than the 0.05 threshold suggested in the literature (Bagozzi \& Yi, 1990). Besides, the amount of variance due to the method factor explains only 4 percent of the total variance, which is much less than the median amount of method variance $(25 \%)$ reported in the literature (Williams, Cote, \& Buckley, 1989). The above findings suggest no serious concern for CMV in this study.

\subsection{Structural Model}

With the measurement model fit and validity ensured, the structural model was tested. The 
structural model fitted the data well according to the following indices: CMIN/DF $=1.547$ $(\mathrm{p}<0.001) ; \mathrm{CFI}=0.974 ;$ AGFI $=0.902 ; \mathrm{RMSEA}=0.044 ;$ PCLOSE $=0.80$. The R-square values also implied that the model accounts for a considerable proportion of variance in the dependent variables (client concern $=31.1 \%$, labour practices $=67.1 \%$, human rights $=$ $45.4 \%$, environmental practices $=50.1 \%$, community involvement $\&$ development $=48.7 \%$ ).

Figure 1 depicts the structural model with significant standardized regression estimates. A number of path coefficients were found to be not significant $(p>0.05)$. None of the paths linking the control variable "operation span" and the CSR variables were significant. The path between "organization size" and HR and that between "organization size" and CID were also insignificant. On the other hand, regarding relationship between OG and all other CSR variables (i.e. Hypothesis 1), all paths were significant.

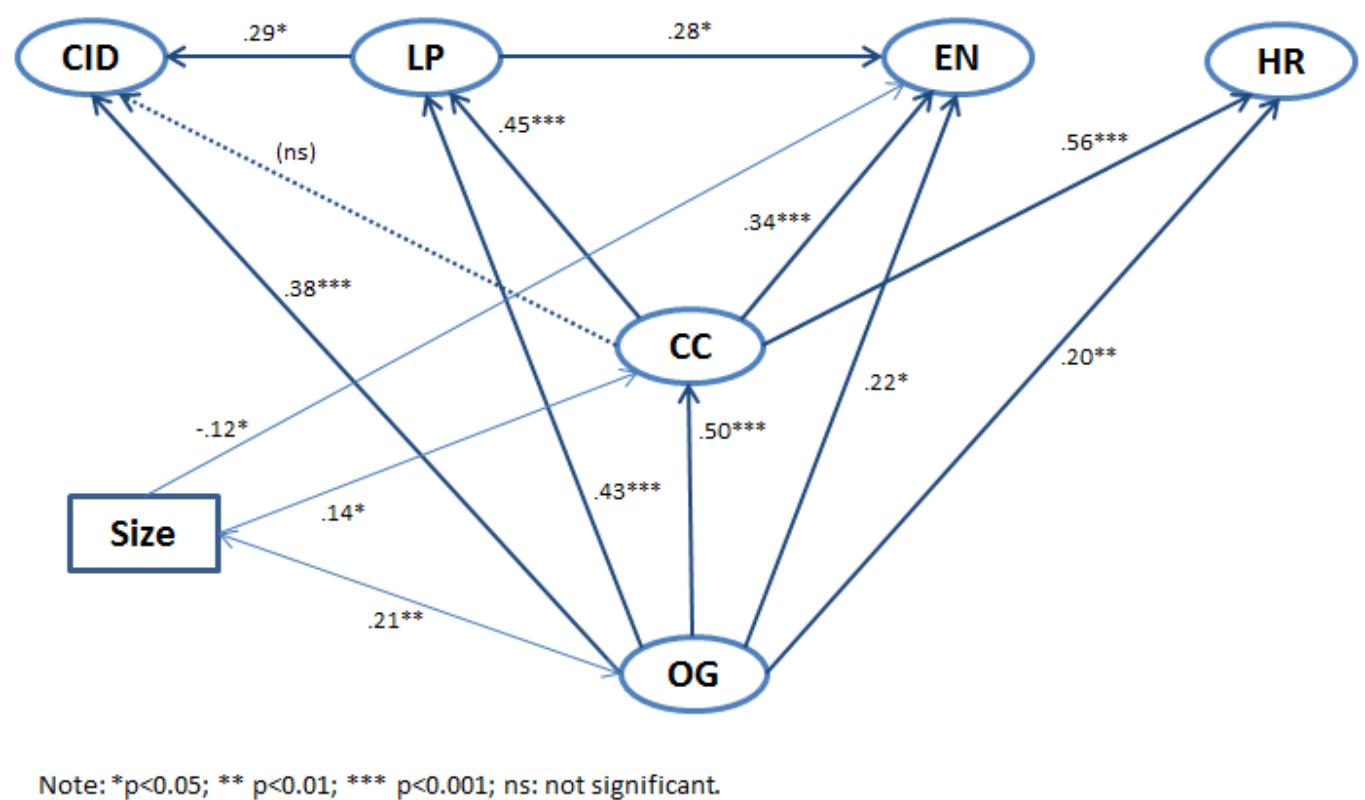

Figure 1. Estimated Structural Model.

(Note: For clarity, measurement items are not shown in the above figure)

\subsection{Tests for Mediation}

In Hypotheses 2 and 3a-b, the mediating effect of client concern and employee concern in the relationship between OG and various CSR practices are examined, respectively. To test complementary mediation, one has to show that (i) both the mediated effect (i.e. the indirect path from the independent variable through the mediator to the dependent variable) and the direct effect (i.e. the direct path from the independent to the dependent variable) are significant; and (ii) both effects have the same sign (Zhao, Lynch, \& Chen, 2010). Accordingly, we follow the procedure by (Gaskin, 2016d) to calculate the bias-corrected bootstrap estimates of the mediated effects (Cheung \& Lau, 2008). The results of the tests support all hypotheses except the mediating effect of $\mathrm{CP}$ on the relationship between OG and 


\section{$\triangle 1$ Macrothink}

CID. Table 3 summarizes the findings of the mediation tests.

Table 3. Results for the Mediation Tests

\begin{tabular}{|c|c|c|c|c|c|c|c|}
\hline \multirow{2}{*}{\multicolumn{2}{|c|}{$\begin{array}{l}\text { Hypothesis for mediation } \\
\text { (Independent } \\
\rightarrow \text { Mediator } \\
\rightarrow \text { Dependent) }\end{array}$}} & \multicolumn{4}{|c|}{ Standardized Estimate (S.E. in brackets) } & \multirow[b]{2}{*}{$\begin{array}{c}\text { Mediation } \\
\text { exists? }\end{array}$} & \multirow[b]{2}{*}{$\begin{array}{c}\text { Type of } \\
\text { mediation }\end{array}$} \\
\hline & & \multirow{2}{*}{$\begin{array}{c}\text { Independent } \\
\rightarrow \begin{array}{c}\text { Mediator } \\
(a)\end{array} \\
.498^{* * *}\end{array}$} & $\begin{array}{c}\text { Mediator } \rightarrow \\
\text { Dependent } \\
(b)\end{array}$ & $\begin{array}{c}\text { Mediated } \\
\text { Effect } \\
(a \times b)\end{array}$ & $\begin{array}{c}\text { Direct Effect } \\
\text { (Independent } \\
\rightarrow \text { Dependent) } \\
(c) \\
\end{array}$ & & \\
\hline $2 a$ & $\mathrm{OG} \rightarrow \mathrm{CC} \rightarrow \mathrm{HR}$ & & $\begin{array}{c}.560 * * * \\
(.120)\end{array}$ & $\begin{array}{l}.262 * * \\
(.058)\end{array}$ & $\begin{array}{l}.200 * * \\
(.065)\end{array}$ & Yes & $\begin{array}{c}\text { Complementary } \\
\text { mediation }\end{array}$ \\
\hline $2 b$ & $\mathrm{OG} \rightarrow \mathrm{CC} \rightarrow \mathrm{EN}$ & $\begin{array}{c}.498 * * * \\
(.047)\end{array}$ & $\begin{array}{l}.338^{* * *} \\
(.146)\end{array}$ & $\begin{array}{l}.168^{*} \\
(.123)\end{array}$ & $\begin{array}{l}.223^{*} \\
(.090)\end{array}$ & Yes & $\begin{array}{c}\text { Complementary } \\
\text { mediation }\end{array}$ \\
\hline $2 \mathrm{c}$ & $\mathrm{OG} \rightarrow \mathrm{CC} \rightarrow \mathrm{LP}$ & $\begin{array}{c}.498^{* * *} \\
(.047)\end{array}$ & $\begin{array}{l}.450^{* * *} \\
(.108)\end{array}$ & $\begin{array}{l}.203^{* * *} \\
(.047)\end{array}$ & $\begin{array}{l}.428 * * * \\
(.066)\end{array}$ & Yes & $\begin{array}{c}\text { Complementary } \\
\text { mediation }\end{array}$ \\
\hline $2 d$ & $\mathrm{OG} \rightarrow \mathrm{CC} \rightarrow \mathrm{CID}$ & $\begin{array}{c}.498 * * * \\
(.047)\end{array}$ & $\begin{array}{l}.110 \\
(.155)\end{array}$ & $\begin{array}{c}.062 \\
(.077)\end{array}$ & $\begin{array}{l}.378^{* * *} \\
(.099)\end{array}$ & No & $\begin{array}{c}\text { Direct effect } \\
\text { only }\end{array}$ \\
\hline $3 a$ & $\mathrm{OG} \rightarrow \mathrm{LP} \rightarrow \mathrm{EN}$ & $\begin{array}{c}.428^{* * *} \\
(.066)\end{array}$ & $\begin{array}{l}.278^{*} \\
(.146)\end{array}$ & $\begin{array}{l}.119 * \\
(.142)\end{array}$ & $\begin{array}{l}.223^{*} \\
(.090)\end{array}$ & Yes & $\begin{array}{c}\text { Complementary } \\
\text { mediation }\end{array}$ \\
\hline $3 b$ & $\mathrm{OG} \rightarrow \mathrm{LP} \rightarrow \mathrm{CID}$ & $\begin{array}{c}.428^{* * * *} \\
(.066) \\
\end{array}$ & $\begin{array}{l}.288^{*} \\
(.160) \\
\end{array}$ & $\begin{array}{l}.139 * \\
(.094) \\
\end{array}$ & $\begin{array}{l}.378 * * * \\
(.099) \\
\end{array}$ & Yes & $\begin{array}{c}\text { Complementary } \\
\text { mediation }\end{array}$ \\
\hline
\end{tabular}

\section{Discussion}

In this section we discuss the main findings from the above structural equation modeling analysis one by one.

The results of our analysis suggest diversified influences of the two control variables under consideration. The control variable "operation span" was found to have no significant effect on any of the CSR constructs. In other words, there is no significant difference in the extent of adoption in all domains of CSR under study between respondent organizations that are locally operated or with overseas operations. A possible reason may lie on the fact that Hong Kong is a metropolitan city with well-established legal and commercial systems. Many ethical values and legal obligations upheld in most developed countries regarding human rights, labour issues and client welfare, are also well observed here. On the other hand, organizations with overseas operation may have environmental initiatives that are relatively more technology-intensive or resource-constrained; yet such techniques may not be applicable in Hong Kong. Finally, as expected, community-oriented CSR practices focus on local community and therefore should not be affected by the operation span of the organization.

Organization size was found to have significant impact on the extent of CSR practices in all areas except those on human rights, and community-oriented practices (constructs HR and CID). Intuitively, its size may affect the scale and the resources an organization acquires to implement socially responsible practices. Adherence to human rights protection, to a large extent, is inherited to an organization's culture and in general does not consume any 
resources. Therefore, our findings are natural and up to general expectation. Interestingly, our analysis suggests no relationship between organization size and community-oriented CSR practices (construct CID). In general, community-oriented CSR practices involve volunteering services and donations. According to Carroll (1991)'s topology of CSR, philanthropic responsibility is more on discretionary basis. At the same time, it is also the most direct and easiest way for any organization to fulfill to its social responsibility. Subsequently, community-oriented CSR practices are readily adopted by all organizations regardless of their scales. Our findings further suggest the perceived extent of community involvement is similar for our respondent organizations with different sizes.

Our survey data supported Hypothesis 1 that organizational governance is positively associated with an organization's approach to different CSR areas. A clear vision and mission to social responsibility helps define the scope and the approach an organization undertakes CSR. For instance, Sharma (2000) posits that perception of senior management towards environmental issues (as opportunities or threats) will affect the nature of the environmental strategy (voluntary or conforming basis) the firm will adopt. A high extent of organizational governance prioritizes the emphasis and resource allocation to different domains of CSR, thus enabling effective planning and execution of various CSR campaigns. Environmental initiatives and community-oriented CSR practices require relatively intensive in finance and labour resources. A supportive management also enables effective implementation in these areas.

Our findings have demonstrated the role of client-oriented CSR practices (construct CP) as a complementary mediator to the association between organizational governance and other areas of CSR (i.e. Hypothesis 2) except community-oriented CSR practices. This reflects the strategic consideration for organizations to implement CSR to a certain extent. By strategically aligning CSR with its objectives to address the needs of its clients, an organization can create shared value that brings benefits to both itself and the society (Porter \& Kramer, 2011). While clients of an organization are directly affected by the organization's client-oriented CSR practices, they may, at the same time, consider the ethical behaviors of the organization towards other stakeholders and the society equally important. As a result, a client-centric organization would also likely expand its focus to other domains of CSR as a responsible corporate citizen, in fulfilling clients' expectation. Interestingly, client-oriented CSR practices was found to have no significant mediating effect on the association between organizational governance and community-oriented CSR practices. The finding confirms the voluntary nature of respondent organizations to get involved in community-related CSR initiatives.

The results of our analysis also confirmed the complementary mediating effect of employee-oriented CSR practices on the relationship between organizational governance and (i) environmental initiatives and (ii) community-oriented CSR practices (Hypotheses 3a and 3b). As the employees are the key personnel to perform the execution, their willingness to collaborate with the organization's objectives and directions attributes to the success of CSR initiatives. In particular, employees with values aligned with those of the organization would be motivated and committed to the effective delivery of CSR activities (Collier \& Esteban, 
2007). In general, community-oriented CSR practices involve a considerable amount of manpower, such as employees' participation in volunteering services. Similarly, a lot of environmental practices, such as energy saving habits and waste classification and recycling, require cooperation of the employees. An organization with more employee-oriented CSR practices would gain a higher level of loyalty and rapport from the employees; in turn the employees would be more proactive to collaborate in the various CSR activities developed by the organization.

\section{Concluding Remarks}

This paper has provided empirical evidence to the importance of organizational governance in the CSR approach undertaken by an organization. Strong support on the strategic considerations of client welfare fulfillment in an organization's approach to CSR is also identified. Specifically, the analysis of survey data confirmed the complementarily mediating role of client-oriented CSR adoption on the relationship between organizational governance and CSR adoption in other domains. Our findings illustrate organizations' endeavors in all areas of CSR to fulfill clients' concern about their social responsibility. Moreover, this paper also asserts that concern for employee welfare enables an organization to perform better in its environmental practices and community-oriented CSR initiatives. A strategic implication is that, for organizations that strive for improvement in their environmental performance and engagement with the local community, more emphasis should be placed on CSR practices with higher orientation towards employees.

This paper acknowledges the limitation owing to the source of sample data. The analysis was based on survey data from a sample of organizations in Hong Kong only. The socio-economic characteristics of the city may affect organizations' perception of CSR and their subsequent implementation. In particular, Hong Kong is a highly civilized cosmopolitan under the influence of both Western economic / legal systems and Eastern cultural / ethical values. Therefore caution should be taken when generalizing the findings. Further investigation with samples of larger sizes and of more diversified profiles (e.g. from cities / countries at different development stages and cultural background) are recommended so that the results could be cross-referenced. Another future research direction could be scrutinizing the relationship between CSR adoption in different domains and organization performance. One could also extend this study to explore the impact of different stakeholders on the strategic CSR approach by organizations.

\section{Acknowledgement}

This research was fully supported by a grant from the Research Grants Council of the Hong Kong Special Administrative Region, China (UGC/IDS12/14).

\section{References}

Abbott, W. F., \& Monsen, R. J. (1979). On the Measurement of Corporate Social Responsibility: Self-Reported Disclosures as a Method of Measuring Corporate Social Involvement. Academy of Management Journal, 22(3), 501-515. http://dx.doi.org/10.2307/255740 
Aguilera, R. V., Williams, C. A., Conley, J. M., \& Rupp, D. E. (2006). Corporate Governance and Social Responsibility: a comparative analysis of the UK and the US. Corporate Governance: An International Review, 14(3), 147-158.

Armstrong, J. S., \& Overton, T. S. (1977). Estimating Nonresponse Bias in Mail Surveys. Journal of Marketing Research, 14, 396-402. http://dx.doi.org/10.2307/3150783

Bagozzi, R. P., \& Yi, Y. (1990). Assessing Method Variance in Multitrait-Multimethod Matrices: The Case of Self-Reported Affect and Perceptions at Work. Journal of Applied Psychology, 75(5), 547-560. http://dx.doi.org/10.1037/0021-9010.75.5.547

Baurn, J. R., Locke, E. A., \& Smith, K. G. (2001). A Multidimensional Model of Venture Growth. The Academy of Management Journal, 44(2), 292-303. http://dx.doi.org/10.2307/3069456

Branco, M. C., \& Rodrigues, L. L. (2006). Corporate Social Responsibility and Resources-Based Perspectives. Journal of Business Ethics, 69, 111-132. http://dx.doi.org/10.1007/s10551-006-9071-z

Brunninge, O., Nordqvist, M., \& Wiklund, J. (2007). Corporate Governance and Strategic Change in SMEs: The Effects of Ownership, Board Composition and Top Management Teams. Small Business Economics, 29, 295-308. http://dx.doi.org/10.1007/s11187-006-9021-2

Byrne, B. M. (2001). Structural equation modeling with AMOS: Basic Concepts, applications, and programming. Mahwah, NJ: Erlbaum.

Carroll, A. B. (1991). The Pyramid of Corporate Social Responsibility: Toward the Moral Management of Organizational Stakeholders. Business Horizons, 34(4), 39-48. http://dx.doi.org/10.1016/0007-6813(91)90005-G

Chang, Y.-Y., Gong, Y., \& Peng, M. W. (2012). Expatriate Knowledge Transfer, Subsidiary Absorptive Capacity, and Subsidiary Performance. Academy of Management Journal, 55(4), 927-948. http://dx.doi.org/10.5465/amj.2010.0985

Cheung, G. W., \& Lau, R. S. (2008). Testing Mediation and Suppression Effects of Latent Variables: Bootstrapping With Structural Equation Models. Organizational Research Methods, 11(2), 296-325. http://dx.doi.org/10.1177/1094428107300343

Cheung, G. W., \& Rensvold, R. B. (2002). Evaluating Goodness-of-Fit Indexes for Testing Measurement Invariance. Structural Equation Modeling, 9(2), 233-255. http://dx.doi.org/10.1207/S15328007SEM0902_5

Child, J. (1997). Strategic Choice in the Analysis of Action, Structure, Organizations and Environment: Retrospect and Prospect. Organization Studies, 18(1), 43-76. http://dx.doi.org/10.1177/017084069701800104

Chow, P.-S., Tang, A. K., \& Yip, A. C. (2016). Scale Development and Operationalization of Social Responsibility Constructs: An ISO 26000 Context. Business and Economic Research, 
6(2), 156-175. http://dx.doi.org/10.5296/ber.v6i2.9865

Clarkson, M. B. (1995). A Stakeholder Framework for Analyzing and Evaluating Corporate Sociasl Performance. Academy of Management Review, 20(1), 92-117.

Cochran, P. L., \& Wood, R. A. (1984). Corporate Social Responsibility and Financial Performance. The Academy of Management Journal, 27(1), 42-56. http://dx.doi.org/10.2307/255956

Collier, J., \& Esteban, R. (2007). Corporate social responsibility and employee commitment. Business Ethics: A European Review, 16(1), 19-33. http://dx.doi.org/10.1111/j.1467-8608.2006.00466.x

Cropamzano, R., \& Mitchell, M. S. (2005). Social Exchange Theory: An Interdisciplanary Review. Journal of Management, 31(6), 874-900. http://dx.doi.org/10.1177/0149206305279602

Daily, B. F., \& Huang, S.-c. (2001). Achieving sustainability through attention to human resource factors in environmental management. International Journal of Operations \& production Management, 21(12), 1539-1552. http://dx.doi.org/10.1108/01443570110410892

Davis, K. (1973). The Case for and against Business Assumption of Social Responsibilities. The Academy of Management Journal, 16(2), 312-322. http://dx.doi.org/10.2307/255331

Delmas, M. A., \& Toffel, M. W. (2008). Organizational Responses to Environmental demands: Opening the Black Box. Strategic Management Journal, 29, 1027-1055. http://dx.doi.org/10.1002/smj.701

Devinney, T. M., Schwalbach, J., \& Williams, C. A. (2013). Editorial - Corporate Social Responsibility and Corporate Governance: Comparative Perspectives. Corporate Governance: An International Review, 21(5), 413-419. http://dx.doi.org/10.1111/corg.12041

Falck, O., \& Heblich, S. (2007). Corporate social responsibility: Doing well by doing good. Business Horizons, 50, 247-254. http://dx.doi.org/10.1016/j.bushor.2006.12.002

Fifka, M. S. (2013). Corporate Responsibility Reporting and its Determinants in Comparative Perspective - a Review of the Empirical Literature and a Meta-analysis. Business Strategy and the Environment, 22, 1-35. http://dx.doi.org/10.1002/bse.729

Galbreath, J. (2010). The impact of strategic orientation on corporate social responsibility. International Journal of Organizational Analysis, 18(1), 23-40. http://dx.doi.org/10.1108/19348831011033195

Gaskin, J. (2012). Confirmatory Factor Analysis. Retrieved from Gaskination's StatWiki: http://statwiki.kolobkreations.com

Gaskin, J. (2016a). Validity Master. Stats Tools Package. Retrieved from http://statwiki.kolobkreations.com

Gaskin, J. (2016b). Group Differences. Stats Tools Package. Retrieved from 
http://statwiki.kolobkreations.com

Gaskin, J. (2016c). SEM Series (2016) 8. Mediation. Retrieved from https://www.youtube.com/watch?v=ICnh3s2FG14

Govindarajulu, N., \& Daily, B. F. (2004). Motivating employees for environmental improvement. Industrial Management \& Data Systems, 104(4), 364-372. http://dx.doi.org/10.1108/02635570410530775

Hair, J., Black, W., Babin, B., \& Anderson, R. (2010). Multivariate Data Analysis (7th ed.). Upper Saddle River, NJ: Prentice-Hall.

Hammann, E.-M., Habisch, A., \& Pechlaner, H. (2009). Values that create value: socially responsible business practices in SMEs - empirical evidence from German companies. Business Ethics: A European Review, 18(1), 37-51. http://dx.doi.org/10.1111/j.1467-8608.2009.01547.x

Hancock, G., \& Mueller, R. (2001). Rethinking construct reliability within latent variable systems. In R. Cudeck, S. du Toit, \& D. Sorbom, Structural Equation Modeling: Present and Future: A Festschrift in honor of Karl Joreskog (pp. 195-214). Lincolnwood: Scientific Software International, Inc.

Harrison, J. S., \& Freeman, R. E. (1999). Stakeholders, Social Responsibility, and Performance: Empirical Evidence and Theoretical Perspectives. Academy of Management Journal, 42(5), 479-485. http://dx.doi.org/10.2307/256971

Ho, C.-K. (2005). Corporate Governance and Corporate Competitiveness: an international analysis. Corporate Governance: An International Review, 13(2), 211-252. http://dx.doi.org/10.1111/j.1467-8683.2005.00419.x

Hu, L.-t., \& Bentler, P. M. (1999). Cutoff criteria for fit indexes in covariance structure analysis: Conventional criteria versus new alternatives. Structural Equation Modeling: A Multidisciplinary Journal, 6(1), 1-55. http://dx.doi.org/10.1080/10705519909540118

Husted, B. W. (2003). Governance Choices for Corporate Social Responsibility: to Contribute, Collaborate or Internalize? Long Range Planning, 36, 481-498. http://dx.doi.org/10.1016/S0024-6301(03)00115-8

Husted, B. W., Allen, D. B., \& Rivera, J. E. (2010). Governance Choice for Strategic Corporate Social Responsibility. Business \& Society, 49(2), 201-215. http://dx.doi.org/10.1177/0007650308315504

Ioannou, I., \& Serafeim, G. (2012). What drives corporate social performance? the role of nation-level institutions. Journal of International Business Studies, 43(9), 834-864. http://dx.doi.org/10.1057/jibs.2012.26

ISO. (2010). ISO 26000:2010 - Guidance on social responsibility. Switzerland: International Organization for Standardization.

Jain, T., \& Jamali, D. (2016). Looking Inside the Black Box: the effect of Corporate 
Governance on Corporate Social Responsibility. Corporate Governance: An International Review, 24(3), 253-273. http://dx.doi.org/10.1111/corg.12154

Jamali, D. (2007). The Case for Strategic Corporate Social Responsibility in Developing $\begin{array}{lllll}\text { Countries. Business and } \quad \text { Society } & \text { Review, }\end{array}$ http://dx.doi.org/10.1111/j.1467-8594.2007.00284.x

Jo, H., \& Harjoto, M. A. (2012). The Causal Effect of Corporate Governance on Corporate Social Responsibility. Journal of Business Ethics, 106, 53-72. http://dx.doi.org/10.1007/s10551-011-1052-1

Johnson, R. E., Rosen, C. C., \& Djurdjevic, E. (2011). Assessing the Impact of Common Method Variance on Higher Order Multidimensional Constructs. Journal of Applied Psychology, 96(4), 744-761. http://dx.doi.org/10.1037/a0021504

Kulik, C. T., Cregan, C., Metz, I., \& Brown, M. (2009). HR Managers as Toxin Handlers: The Buffering Effect of Formalizing Toxin Handling Responsibilities. Human Resources Management, 48(5), 695-716. http://dx.doi.org/10.1002/hrm.20311

Lo, C. K., Yeung, A. C., \& Cheng, T. (2012). The impact of environmental management systems on financial performance in fashion and textiles industries. International Journal of Production Economics, 561-567. http://dx.doi.org/10.1016/j.ijpe.2011.05.010

Lynch, P. D., Eisenberger, R., \& Armeli, S. (1999). Perceived Organizational Support: Inferior Versus Superior Performance by Wary Employees. Journal of Applied Psychology, 84(6), 467-483. http://dx.doi.org/10.1037/0021-9010.84.4.467

Machold, S., Huse, M., Minichilli, A., \& Nordqvist, M. (2011). Board Leadership and Strategy Involvement in Small Firms: A Team Production Approach. Corporate Governance: An International Review, 19(4), 368-383. http://dx.doi.org/10.1111/j.1467-8683.2011.00852.x

McGuire, J. B., Sundgren, A., \& Schneeweis, T. (1988). Corporate Social Responsibility and Firm Financial Performance. The Academy of Management Journal, 31(4), 854-872. http://dx.doi.org/10.2307/256342

McWilliams, A., \& Siegel, D. (2001). Corporate Social Responsibility: A Theory of the Firm Perspective. Academy of Management Review, 26(1), 117-127.

McWilliams, A., \& Siegel, D. S. (2011). Creating and Capturing Value: Strategic Corporate Social Responsibility, Resource-Based Theory, and Sustainable Competitive Advantage. Journal of Management, 37(5), 1480-1495. http://dx.doi.org/10.1177/0149206310385696

Meyer, J. P., \& Smith, C. A. (2000). HRM Practices and Organizational Commitment: Test of a Mediation Model. Canadian Journal of Administrative Sciences, 17(4), 319-331. http://dx.doi.org/10.1111/j.1936-4490.2000.tb00231.x

Ntim, C. G., \& Soobaroyen, T. (2013). Corporate Governance and Performance in Socially Responsible Corporations: New Empirical Insights from a Neo-Institutional Framework. Corporate Governance: An International Review, 21(5), 468-494. 
http://dx.doi.org/10.1111/corg.12026

Nunnally, J. C. (1978). Psychometric Theory (2nd ed.). New York: McGraw-Hill.

Perez-Batres, L. A., Doh, J. P., Miller, V. V., \& Pisani, M. J. (2012). Stakeholder Pressures as Determinants of CSR Strategic Choice: Why do Firms Choose Symbolic Versus Substantive Self-Regulatory Codes of Conduct? Journal of Business Ethics, 110, 157-172. http://dx.doi.org/10.1007/s10551-012-1419-y

Podsakoff, P. M., MacKenzie, S. B., Lee, J.-Y., \& Podsakoff, N. P. (2003). Common Method Biases in Behavioral Research: A Critical Review of the Literature and Recommended

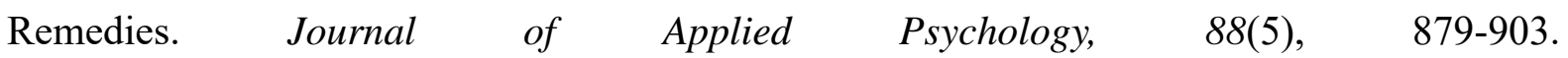
http://dx.doi.org/10.1037/0021-9010.88.5.879

Podsakoff, P. M., MacKenzie, S. B., \& Podsakoff, N. P. (2012). Sources of Method Bias in Social Science Research and Recommendations on How to Control It. The Annual Review of Psychology, 63, 539-569. http://dx.doi.org/10.1146/annurev-psych-120710-100452

Polonsky, M., \& Jevons, C. (2009). Global branding and Strategic CSR: an overview of three types of complexity. International Marketing Review, 26(3), 327-347. http://dx.doi.org/10.1108/02651330910960816

Porter, M. E., \& Kramer, M. R. (2002). The Competitive Advantage of Corporate Philanthropy. Harvard Business Review, 80(12), pp. 56-69.

Porter, M. E., \& Kramer, M. R. (2006). Strategy \& Society: The Link Between Competitive Advantage and Corporate Social Responsibility. Harvard Business Review, 84(12), 78-92.

Porter, M. E., \& Kramer, M. R. (2011). Creating Shared Value: How to reinvent capitalism and unleash a wave of innovation and growth. Harvard Business Review, 89(1/2), 62-77.

Rhodes, M. L., \& Keogan, J. F. (2005). Strategic Choice in the Non-Profit Sector: Modelling the Dimensions of Strategy. The Irish Journal of Management, 26(1), 122-135.

Saeidi, S. P., Sofian, S., Saeidi, P., Saeidi, S. P., \& Saaeidi, S. A. (2015). How does corporate social responsibility contribute to firm financial performance? The mediating role of competitive advantage, reputation, and customer satisfaction. Journal of Business Research, 68, 341-350. http://dx.doi.org/10.1016/j.jbusres.2014.06.024

Saks, A. M. (2006). Antecedents and consequences of employee engagement. Journal of Managerial Psychology, 21(7), 600-619. http://dx.doi.org/10.1108/02683940610690169

Sarkis, J., Gonzalez-Torre, P., \& Adenso-Diaz, B. (2010). Stakeholder pressure and the adoption of environmental practices: The mediating effect of training. Journal of Operations Management, 28, 163-176. http://dx.doi.org/10.1016/j.jom.2009.10.001

Schwartz, M. S., \& Carroll, A. B. (2003). Corporate Social Responsibility: A Three-Domain Approach. Business Ethics Quarterly, 13(4), 503-530. http://dx.doi.org/10.5840/beq200313435 


\section{Macrothink}

Journal of Management Research

ISSN 1941-899X 2016, Vol. 8, No. 4

Sharma, S. (2000). Managerial Interpretations and Organizational Context as Predictors of Corporate Choice of Environmental Strategy. Academy of Management Journal, 43(4), 681-697. http://dx.doi.org/10.2307/1556361

Suchman, M. C. (1995). Managing Legitimacy: Strategic and Institutional Approaches. The Academy of Management Review, 20(3), 571-610.

Vandenberg, R. J., \& Lance, C. E. (2000). A Review and Synthesis of the Measurement Invariance Literature: Suggestions, Practices, and Recommendations for Organizational Research. Organizational Research Methods, 3(1), 4-70. http://dx.doi.org/10.1177/109442810031002

Waddock, S. A., \& Graves, S. B. (1997). The Corporate Social Performance - Financial Performance Link. Strategic Management Journal, 18(4), 303-319. http://dx.doi.org/10.1002/(SICI)1097-0266(199704)18:4<303::AID-SMJ869>3.0.CO;2-G

Williams, L. J., Cote, J. A., \& Buckley, M. R. (1989). Lack of Method Variance in Self-Reported Affect and Perceptions at Work: Reality or Artifact? Journal of applied Psychology, 74(3), 462-468. http://dx.doi.org/10.1037/0021-9010.74.3.462

Wood, D. J. (1991). Corporate social Performance Revisited. Academy of Management Review, 4, 691-718.

Zhao, X., Lynch, J. G., \& Chen, Q. (2010). Reconsidering Baron and Kenny: Myths and Truths about Mediation Analysis. Journal of Consumer Research, 37, 197-206. http://dx.doi.org/10.1086/651257

\section{Copyright Disclaimer}

Copyright for this article is retained by the author(s), with first publication rights granted to the journal.

This is an open-access article distributed under the terms and conditions of the Creative Commons Attribution license (http://creativecommons.org/licenses/by/3.0/). 